\title{
INDICADORES BIOFÍSICOS DE DESERTIFICAÇÃO, CABO VERDE/ÁFRICA
}

\author{
biophysical indicators of desertification, Cape VerdelAfrica
}

Vládia Pinto Vidal de Oliveira*

\begin{abstract}
Resumo
O trabalho discute o diagnóstico geoambiental da Ilha de Santiago de Cabo Verde. Objetiva avaliar a dinâmica ambiental e o estado de evolução dos sistemas naturais, estabelecendo as categorias de meios ecodinâmicos. Cada categoria de meio está associada ao comportamento e à vulnerabilidade das condições geoambientais em função dos processos degradacionais. Sob o ponto de vista teórico-metodológico, adotaram-se critérios integrativos capazes de atender às relações de interdependência entre componentes físico-bióticos e socioeconômicos. Selecionaram-se 7 (sete) indicadores biofísicos: geologia, geomorfologia, cobertura vegetal (estratificação), cobertura vegetal (percentual de ocupação), solos (espessura) e solos (erosão). Resultaram 10 (dez) sistemas ambientais, que, na análise dos Indicadores Biofísicos de Desertificação (IBFD), apontaram a ocorrência de dois grupos distintos: índice muito alto de desertificação e de muito baixo a baixo índice biofísico de desertificação.
\end{abstract}

Palavras-chave: Sistemas ambientais, ecodinâmica, indicadores de desertificação,

\section{Abstract}

The paper discusses the diagnosis of geoenvironmental Santiago Island in Cape Verde. To evaluate the environmental and dynamic state of evolution of natural systems, establishing the categories of means ecodynamics. Each category of medium is associated with the behavior and vulnerability conditions in terms of geo-environmental degradation processes. From the theoretical point of view, methodological criteria were adopted integrative cover SEZ to meet the interdependencies between physical and biotic components and socioeconomic factors. We selected seven (7) biophysical indicators: geology, geomorphology, vegetation cover (stratification), vegetation cover (percentage of occupancy), soil (thickness) and soils (erosion). Resulted in 10 (ten) environmental systems, which, in the analysis of biophysical indicators of Desertification (IBFD), showed the occurrence of two distinct groups: very high rate of desertification and very low to low biophysical desertification.

Key words: Environmental Systems, ecodynamics, indicators of desertification

\section{Resumen}

El trabajo discute el diagnostico geoambiental de la Isla de Santiago de Cabo Verde. Tiene como objetivo evaluar la dinámica ambiental y el estado de evolución de los sistemas naturales, estableciendo las categorías de los medios ecodinámicos. Cada categoría del medio está asociada al comportamiento y a la vulnerabilidad de las condiciones geoambientales en función de los procesos de degradación. Sobre el punto de vista teórico-metodológico, se adoptaron criterios integrativos capaces de atender a las relaciones de interdependencia entre componentes físico-bióticos y socioeconómicos. Se seleccionaron siete (7) indicadores biofísicos: geología, geomorfología, cobertura vegetal (estratificación), cobertura vegetal (porcentual de ocupación), suelos (espesura) y suelos (erosión). Resultaron diez (10) sistemas ambientales, que, en el análisis de los Indicadores Biofísicos de Desertificación (IBFD), apuntaron a la ocurrencia de dos grupos distintos: índice muy alto de desertificación y de muy bajo a bajo índice biofísico de desertificación.

Palabras clave: Sistemas ambientales, ecodinámica, indicadores de desertificación.

(*) Bolsista Produtividade CNPq, Prof ${ }^{\mathrm{a}}$. Dr ${ }^{\mathrm{a}}$. da Pós Graduação em Geografia Universidade Federal do Ceará - Campus do Pici, Bloco 911, CEP: 60.455-760, Fortaleza (CE) - Brasill, Tél./Fax.: (+ 55 85) 3366-9855 / 3366.9864 - vlpinto@ufc.br 


\section{INTRODUÇÃO}

A Ilha de Santiago compõe uma das 10 (dez) ilhas que integram o arquipélago de Cabo Verde (África). Destaca-se por apresentar o maior contingente demográfico do arquipélago e maior pressão sobre a base dos recursos naturais. A espacialização demográfica possui dois quadros proeminentes: de interiorização e de ocupação da faixa litorânea. A ocupação interior está afeta à melhoria das condições edáficas das ribeiras, onde a agricultura é praticada com maior intensidade, principalmente nos setores de maior umidade, favorecidos pela altitude. A faixa litorânea tem a função urbano-portuária como predominante, remontando ao período da exploração colonial.

Os estudos físico-ambientais têm assumido significativa relevância, pois são usados para estabelecer as diretrizes das políticas de meio ambiente. Os resultados e experiências alcançados se baseiam em modelo sistêmico, revelando-se adequados para incorporar a variável ambiental ao processo de organização territorial e de sustentabilidade. O modelo sistêmico considera o ambiente como um sistema complexo, que deriva das relações mútuas e interações entre componentes do potencial ecológico e os componentes da exploração biológica. Essas relações assumem um grau maior de complexidade quando são incorporadas às variáveis de uso e à ocupação da terra (SOUZA, 2000).

Os sistemas ambientais tendem a apresentar um arranjo espacial decorrente da similaridade de relações entre os componentes naturais de aspecto geológico, geomorfológico, hidroclimático, pedológico e bioecológico - materializando-se nos diferentes padrões de paisagens.

Parte-se do pressuposto básico de que os sistemas ambientais são integrados por variados elementos que mantêm relações mútuas e são continuamente submetidos aos ciclos da matéria e fluxo de energia. Cada sistema representa uma unidade de organização do ambiente natural. Em cada sistema, verifica-se, comumente, um relacionamento harmônico entre seus componentes, sendo estes dotados de potencialidades e limitações específicas, sob o ponto de vista de recursos ambientais. Como tal, reagem também de forma singular no que tange às condições de uso e ocupação.

Considerando os pressupostos estabelecidos, o trabalho trata do diagnóstico geoambiental da Ilha de Santiago de Cabo Verde, dando ênfase ao conhecimento integrado e à delimitação dos espaços territoriais modificados ou não pelos fatores econômicos e sociais. Buscou-se conhecer a dinâmica e o estado de degradação em que se encontram os sistemas ambientais estabelecendo-se os indicadores biofísicos de desertificação para esses sistemas.

\section{PROCEDIMENTOS METODOLÓGICOS}

Os resultados do diagnóstico ambiental do meio físico-biótico decorreram de uma revisão sistemática dos levantamentos anteriormente procedidos sobre a base dos recursos naturais da ilha de Santiago do arquipélago de Cabo Verde. As análises desse material, os produtos de sensoriamento remoto e a comprovação em campo constituíram os meios utilizados para a concretização desse estudo.

As análises temáticas foram realizadas de modo a demonstrar o estreito relacionamento mútuo entre os componentes geoambientais. O diagnóstico do meio físico apresenta uma proposta de síntese da compartimentação geoambiental mediante quadro sinóptico. Visa-se, com isso, a atender aos pressupostos de uma análise integrada do ambiente físico-natural e ao seu comportamento, subsidiando mecanismos capazes de conduzir ao ordenamento territorial.

Nessa etapa do diagnóstico, é priorizada a visão de totalidade para a caracterização das unidades geossistêmicas. Destacam-se, nesse aspecto, as concepções metodológicas consagradas em trabalhos ligados aos diagnósticos e zoneamentos ambientais.

Com o objetivo de avaliar a dinâmica ambiental e o estado de evolução dos sistemas naturais, são estabelecidas categorias de meios ecodinâmicos, com base em adaptações dos critérios de Tricart (1977) e Souza (2000). Cada categoria de meio está associada ao comportamento e à vulnerabilidade das condições geoambientais em função dos processos degradacionais.

Adaptando-se os critérios para a área em foco, são distinguidas três categorias de meios relacionadas e sumariamente caracterizadas abaixo:

- ambientes estáveis - apresentam estabilidade morfogenética antiga em função da fraca atividade do potencial erosivo. Os processos morfogenéticos e pedogenéticos possuem um balanço favorável à pedogênese ou em equilíbrio entre os fatores do potencial ecológico e os 
de exploração biológica. O recobrimento vegetal é pouco alterado pelas ações antrópicas, ou existe forte regeneração da cobertura secundária, a qual evolui para as condições próximas às originais;

- ambientes de transição - relacionam-se à dinâmica atual do ambiente, que é marcada pelo rompimento incipiente do equilíbrio ecológico. Há preponderância dos processos morfogenéticos sobre os pedogenéticos, embora de forma tênue, o que pode favorecer uma ou outra condição: predominância dos processos pedogenéticos indica tendência à estabilidade; predominância dos processos morfogenéticos demonstra tendência à instabilidade;

- ambientes instáveis - apresentam uma intensa atividade do potencial erosivo com nítidas evidências de deterioração ambiental e da capacidade produtiva dos recursos naturais. $\mathrm{O}$ balanço entre a morfogênese e a pedogênese é favorável à morfogênese. Esses ambientes poderão ser subdivididos em duas categorias: ambientes de baixa instabilidade e ambientes de forte instabilidade. No primeiro caso, há ainda certa frequência das comunidades vegetais primárias. No segundo, há evidente primazia da perda do material pedogenético e da cobertura vegetal que foram quase suprimidas.

Com o enquadramento em uma determinada categoria de meio ecodinâmico, viabiliza-se a possibilidade de detectar o grau de vulnerabilidade do ambiente e sua sustentabilidade futura, tendencial e desejada.

Após a caracterização do contexto geoambiental da área e selecionados os indicadores de desertificação, foi organizado um Quadro Sinóptico dos Sistemas Ambientais, contemplando, sequencialmente, os seguintes aspectos: (a) sistemas ambientais; (b) características naturais dominantes e ecodinâmica da paisagem; (c) problemas ambientais; (d) capacidade de suporte, incluindo condições de potencialidades e limitações; (e) cenários tendenciais e desejáveis.

As potencialidades são tratadas como atividades ou condições que têm exequibilidades de serem praticadas em cada sistema ambiental, sendo propícias à instalação de infraestruturas ou de atividades econômicas propriamente ditas.

As limitações ao uso produtivo foram identificadas com base nas vulnerabilidades e nas deficiências do potencial produtivo dos recursos naturais e no estado de conservação da natureza, em função dos impactos produzidos pela ocupação da terra.

Sob o ponto de vista teórico-metodológico, a abordagem sistêmica integra o conjunto das variáveis ambientais envolvidas no processo e de cujas relações de reciprocidade decorrem os sistemas ou unidades ambientais. A valorização da multidisciplinaridade é fundamental, na medida em que se considera o aspecto amplo de atividades e estudos envolvidos. Pressupõe-se um conhecimento pormenorizado da realidade socioambiental, necessitando o envolvimento de profissionais de diversas especialidades. A prognose requer a elaboração de cenários que simulam situações, vislumbram soluções e orientam a escolha de possíveis alternativas (BRASIL, 2001).

Na elaboração do diagnóstico geoambiental, as análises setoriais apenas serviram de meio para integração dos componentes. Adotaram-se procedimentos que conduziram à delimitação dos sistemas ambientais em consonância com pressupostos metodológicos integrativos capazes de apreender as relações de interdependência entre componentes físico-bióticos e socioeconômicos.

Os sistemas ambientais estão configurados em mapa organizado em escala compatível com base na interpretação de imagens orbitais e com rigoroso controle de campo. O estudo biofísico serve para o entendimento das relações sociais, econômicas e da organização do espaço, enfocando as principais potencialidades e limitações.

Os indicadores biofísicos de desertificação (IBFD) foram analisados por meio de Sistema de Informação Geográfico e constatação em campo, baseado-se na metodologia de Abraham e Beekman (2006) e Oliveira (2003), que destacaram alguns parâmetros como geologia, geomorfologia, vegetação, cobertura vegetal (estratificação), cobertura vegetal natural, solos, erosão e condições climáticas (Quadro 1). Os indicadores foram organizados pressupondo que os maiores valores correspondem às melhores potencialidades para a conservação ambiental. Desse modo, resultará que o maior valor do índice biofísico de desertificação (IBFD) indicará menor estado de conservação. 
A desertificação é definida como "[...] degradação das terras em regiões áridas, semiáridas e subúmidas secas, desencadeada por fatores diversos, tais como variações climáticas e ação antrópica" (BRASIL, 2004). Baseado nessa concepção, o termo desertificação significa a expressão geral dos processos biofísicos, naturais e induzidos, assim como sociais e econômicos, que rompem o equilíbrio ecológico das terras secas.

Quadro 1 - Indicadores biofísicos de desertificação

\begin{tabular}{|c|c|c|}
\hline \multicolumn{3}{|c|}{ INDICADORES BIOFÍSICOS DE DESERTIFICAÇÃO } \\
\hline - Geologia ( Litotipos / Permeabilidade ) - IBFD1 & & V.I. \\
\hline Cobertura não coesas & & $(5)$ \\
\hline Capeamento arenítico & & (4) \\
\hline Litotipos arenito-basaltícos & & (3) \\
\hline Exposições basálticas & & (2) \\
\hline Basalto e outros produtos vulcânicos & & $(1)$ \\
\hline Geomorfologia (Declividade / topográfico) - IBFD2 & Faixa & V.I. \\
\hline Plano & $0-3 \%$ & $(5)$ \\
\hline Suave ondulado & $3-8 \%$ & (4) \\
\hline Ondulado & $8-15 \%$ & (3) \\
\hline Fortemente ondulado & $15-45 \%$ & (2) \\
\hline Montanhoso & $>45 \%$ & $(1)$ \\
\hline - $\quad$ Cobertura Vegetal (Estratificação) - IBFD3 & Faixa & V.I. \\
\hline Estrato arbóreo & $+5 \mathrm{~m}$ & $(5)$ \\
\hline Estrato arbóreo médio-alto & $3-5 \mathrm{~m}$ & (4) \\
\hline Estrato arbustivo médio & $1-3 \mathrm{~m}$ & (3) \\
\hline Estrato arbustivo baixo & $0,5-1 \mathrm{~m}$ & (2) \\
\hline \multicolumn{2}{|l|}{ Pastos / cultivos / sem vegetação } & $(1)$ \\
\hline - $\quad$ Cobertura Vegetal (Percentual de Ocupação)- IBFD4 & Faixa & V.I. \\
\hline Alto & $>75 \%$ & $(5)$ \\
\hline Médio-alto & $54-75 \%$ & (4) \\
\hline Médio & $32-53 \%$ & (3) \\
\hline Médio-baixo & $10-31 \%$ & (2) \\
\hline Inferior a $10 \%$ & $<10 \%$ & (1) \\
\hline - $\quad$ Solos ( Espessura ) - IBFD5 & Faixa & V.I. \\
\hline Muito profundos & $>200 \mathrm{~cm}$ & (5) \\
\hline Profundos & $100-200 \mathrm{~cm}$ & (4) \\
\hline Moderadamente rasos & $50-100 \mathrm{~cm}$ & (3) \\
\hline Raso & $25-50 \mathrm{~cm}$ & (2) \\
\hline Muito rasos e afloramentos rochosos & Sem solo $<25 \mathrm{~cm}$ & $(1)$ \\
\hline - $\quad$ Solos (Erosão) - IBDF6 & Faixa & V.I. \\
\hline \multicolumn{2}{|l|}{ Baixa susceptibilidade } & $(5)$ \\
\hline \multicolumn{2}{|l|}{ Erosão em sulcos } & (4) \\
\hline Erosão com ravinas & Profundidade $<100 \mathrm{~cm}$ & (3) \\
\hline Ravinas/voçorocas & $100-200 \mathrm{~cm}$ & (2) \\
\hline Voçorocas & Profundidade $>200 \mathrm{~cm}$ & $(1)$ \\
\hline - $\quad$ Zonação Climática - IBFD7 & Faixa & V.I. \\
\hline Zona úmida & $>700$ & $(5)$ \\
\hline Zona subúmida & Pluviometria entre 600 & (4) \\
\hline Zona subúmida a semiárida a árida & Pluviometria entre $400-600 \mathrm{~mm}$ & (3) \\
\hline Zona árida a semiárida & Pluviometria entre $300-400 \mathrm{~mm}$ & (2) \\
\hline Zona árida & Pluviometria inferior a $300 \mathrm{~mm}$. & (1) \\
\hline
\end{tabular}

É indispensável o estudo holístico e sistêmico dos aspectos envolvidos, já que a luta contra a desertificação é uma aplicação de medidas preventivas nas terras que ainda não foram afetadas pela degradação 
ou que ainda estejam em estágio inicial. Desse modo, o estudo de indicadores biofísicos é considerado um atributo quali-quantitativo de um determinado problema e/ou processos (FAO-PNUMA 1984 apud NAVONE et al. 2006, p.104).

\section{CONTEXTUALIZAÇÃO GEOAMBIENTAL E OS RECURSOS NATURAIS}

\section{Localização e aspectos gerais}

A ilha de Santiago (Figura 1), cuja capital é a cidade de Praia, situa-se a cerca de $500 \mathrm{~km}$ da Costa Ocidental da África, entre os meridianos $23^{\circ} 26^{\prime}$ e $23^{\circ} 48^{\prime}$ de longitude Oeste e paralelos de $14^{\circ} 54^{\prime}$ e $15^{\circ} 20^{\prime}$ de latitude Norte. É a maior ilha do arquipélago, apresentando uma forma alongada no sentido SE-NW, com um comprimento de $55 \mathrm{~km}$ e uma largura máxima de $37 \mathrm{~km}$ no sentido de E-W, perfazendo um total em extensão de aproximadamente $1.005 \mathrm{~km}^{2}$. Segundo o Censo 2000, o efetivo populacional corresponde a 234.940 habitantes, o que equivale à metade de todo o arquipélago. A ilha tem temperaturas amenas em função da maritimidade e da altitude proporcionada pelo relevo montanhoso. Cultivam-se cereais, tabaco, cana-de-açúcar e laranja. O mercado multicolorido local e os monumentos da Cidade Velha, São Jorge dos Órgãos, Assomada e o balneário Tarrafal são os principais atrativos turísticos e culturais da cidade.
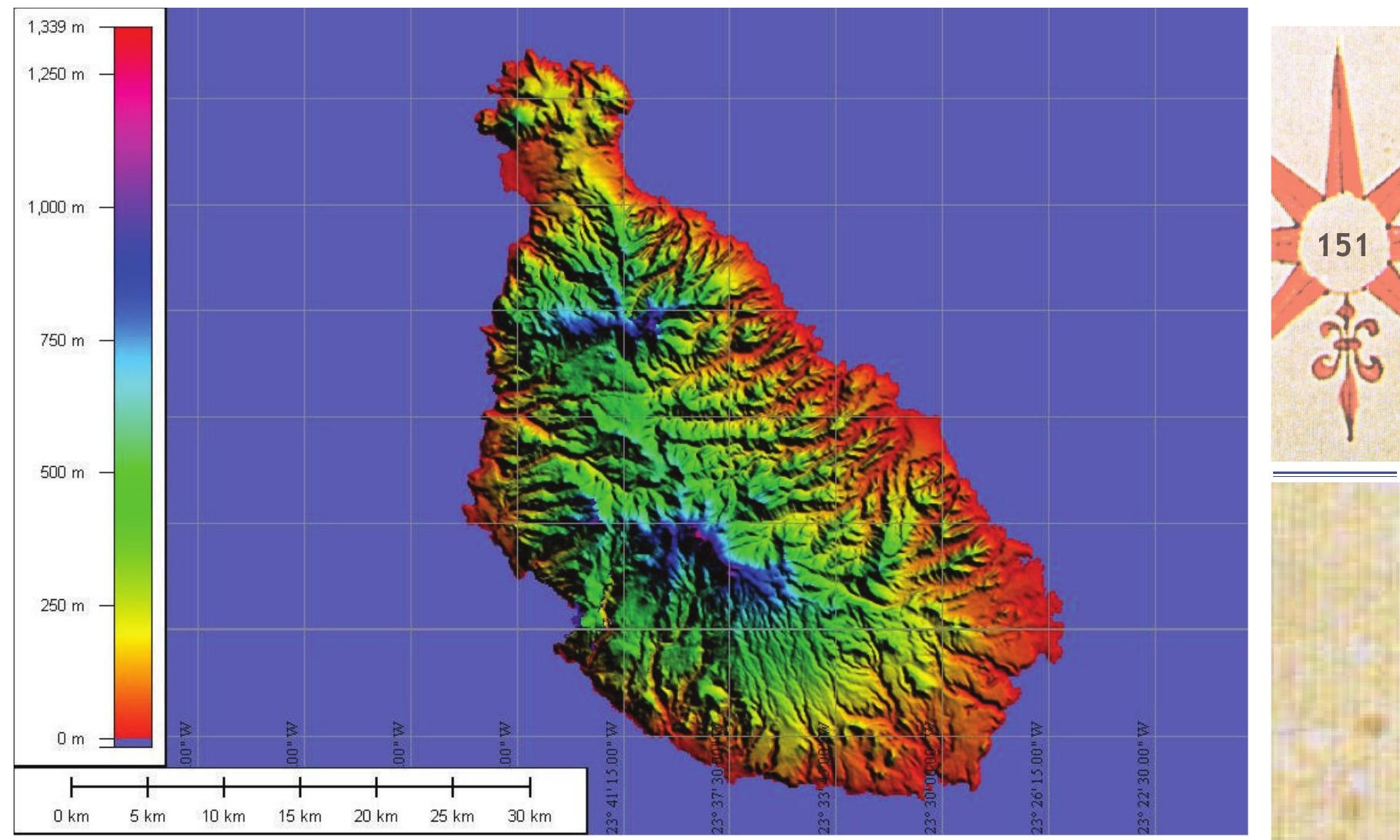

Figura 1 - Imagem da Ilha de Santiago Fonte: GOOGLE, 2010

\section{Bases geológicas e geomorfológicas}

A compartimentação gemorfológica da Ilha de Santiago está delimitada pelas estruturas geológicas e feições do modelado com base no predomínio litológico e elementos geotectônicos. Trata-se de interpretar o jogo de relação da estrutura por meio da disposição das rochas na superfície, dos tipos de estratificação e do comportamento das rochas em face da ação dos processos morfoclimáticos. É constituída, essencialmente, por materiais de origem vulcânica, dividida em duas grandes séries eruptivas fundamentais, intercaladas em muitos pontos do litoral e interior de alguns vales por formações sedimentares. A mais antiga (provavelmente cretácea ou pré-mioceno) e mais profunda constitui o substrato de toda a ilha, sendo constituída por 
basaltos olivínicos, levemente alcalinos, tufos brechoides de blocos de basaltos, massas de tufos e basaltos com estrutura em pillow-lava, glomérulos basálticos muitas vezes cimentados por uma massa calcária no litoral (AMARAL, 2007; MARQUES, 1990).

Pressupõe-se que, durante algum tempo, a série de base emergisse, ficando sob a ação dos agentes erosivos que modelaram uma superfície posteriormente inumada por depósitos sedimentares, ou por materiais eruptivos da série mais recente.

Configura-se, de modo geral, em uma morfologia bastante complexa uma vez que associa montanhas com vertentes de grande declive, barrancos profundos, vales amplos e extensas superfícies planas ("Achadas") , além de uma superfície planáltica no centro oriental da ilha. A ínsula possui poucas áreas planas exceto na porção central truncada por superfícies de erosão escalonadas que se suavizam em direção ao litoral, terminando nas superfícies aplainadas. Apresenta vales com vertentes abruptas e estreitas planícies aluviais ao longo dos rios que demandam a linha de costa. A sequência vulcano-estratigráfica da ilha, estabelecida por Serralheiro et. al (1973) e Serralheiro (1976), destaca as seguintes unidades lito-estratigráficas (Figura 3), as quais, neste trabalho, estão associadas aos macrocompartimentos do relevo, adaptado de Amaral (2007):

Maciços do Pico de Antónia e da Serra Malagueta - constituem relevos que se sobressaem na ilha, correspondendo aos flancos de aparelhos vulcânicos que abrangem o setor central, com altitudes superiores a $700 \mathrm{~m}$, destacando ressaltos como: Pico de Antónia (1.394 m); Gamboa (1.099m); Tagarrinho (1.035) e Grande (878). Desenvolvem-se em material da Formação Pico de Antónia, constituído essencialmente por rochas do Complexo Antigo Interno (CA), que correspondem às formações mais antigas datadas do Paleogénico. Distinguem-se várias subunidades de fácies marinha e terrestre, separadas por superfícies de erosão e de sedimentação em que as séries lávicas fossilizam vales antigos. Foram formados por atividade exclusivamente submarina, quando extrusiva, onde as atuais evidênias devem corresponder aos relevos residuais exumados pela erosão;

- Planaltos Interiores de Santa Catarina - planaltos com superfície plana a ligeiramente ondulada em uma altitude média de $500 \mathrm{~m}$ na parte central da ilha, representada pela Formação de Assomada que é constituída por material eruptivo como mantos e piroclastos subaéreos (basanitos, ancaratrítos, basaltos limburgíticos etc.), que representa uma fase tardia do Complexo do Pico de Antonia (PA) do Pliocenio;

. Patamares (“Achadas") Parcialmente Dissecados e Aplainados - correspondem a uma superfície estrutural definida pelos mantos de estrutura colunar sobreposta horizontalmente pela série de base deformada e truncada por filões. Apresentam características gerais de cornijas sobre os mantos de basaltos, intercaladas por materiais sedimentares da Formação dos Órgãos ou dos Flamengos. Muitos deles têm um traçado rígido e normalmente os fundos são largos e planos. Os de superfície plana correspondem às planuras litorâneas com níveis altimétricos entre 10 e 20 m na Ponta Leste, passando de 60 a 70 m nas planuras de São Francisco e Grande, entre as cidades da Praia e Gouveia, apresentando vários níveis escalonados de terraços marinhos. Na planura do Forte, nas proximidades da cidade Velha, chega a mais de $100 \mathrm{~m}$. Esse conjunto direciona-se suavemente para o maciço do Pico de Antónia, onde surgem os patamares parcialmente dissecados, cortados por vales pouco encaixados;

- Superfície Dissecada em Cristas - corresponde às vertentes onde os relevos são fortemente dissecados por vales profundos com interflúvios culminando em cristas constituídas por mantos de basaltos da Formação do Pico de Antónia e Formação dos Flamengos (mantos e piroclastos). O aspecto estrutural, o tipo de dissecação e as formas do relevo resultaram em vales muito retilíneos e profundos. São evidências que caracterizam um tipo de forma em que a morfologia vulcânica recebe a denominação dada por Amaral (2007) de planèze;

- Coroamento Rochoso - corresponde aos domos e chaminés dispersos em toda ilha na forma de montes, com topos arredondados em rochas fonolíticas e basálticas, mantos subaéreos, brechas e piroclastos de rochas fonolíticas da Formação Pico de Antónia; 
- Cones Vulcânicos - apresentam-se distribuídos por toda a ilha. Encontram-se nos mais diferentes estados de destruição, fortemente alterados e erodidos. São constituídos de material piroclástico e pequenos derrames das últimas fases eruptivas da ilha, datando do pleistoceno. Esses cones se assentam sobre o nível das achadas litorâneas e do planalto central de Santa Catarina.

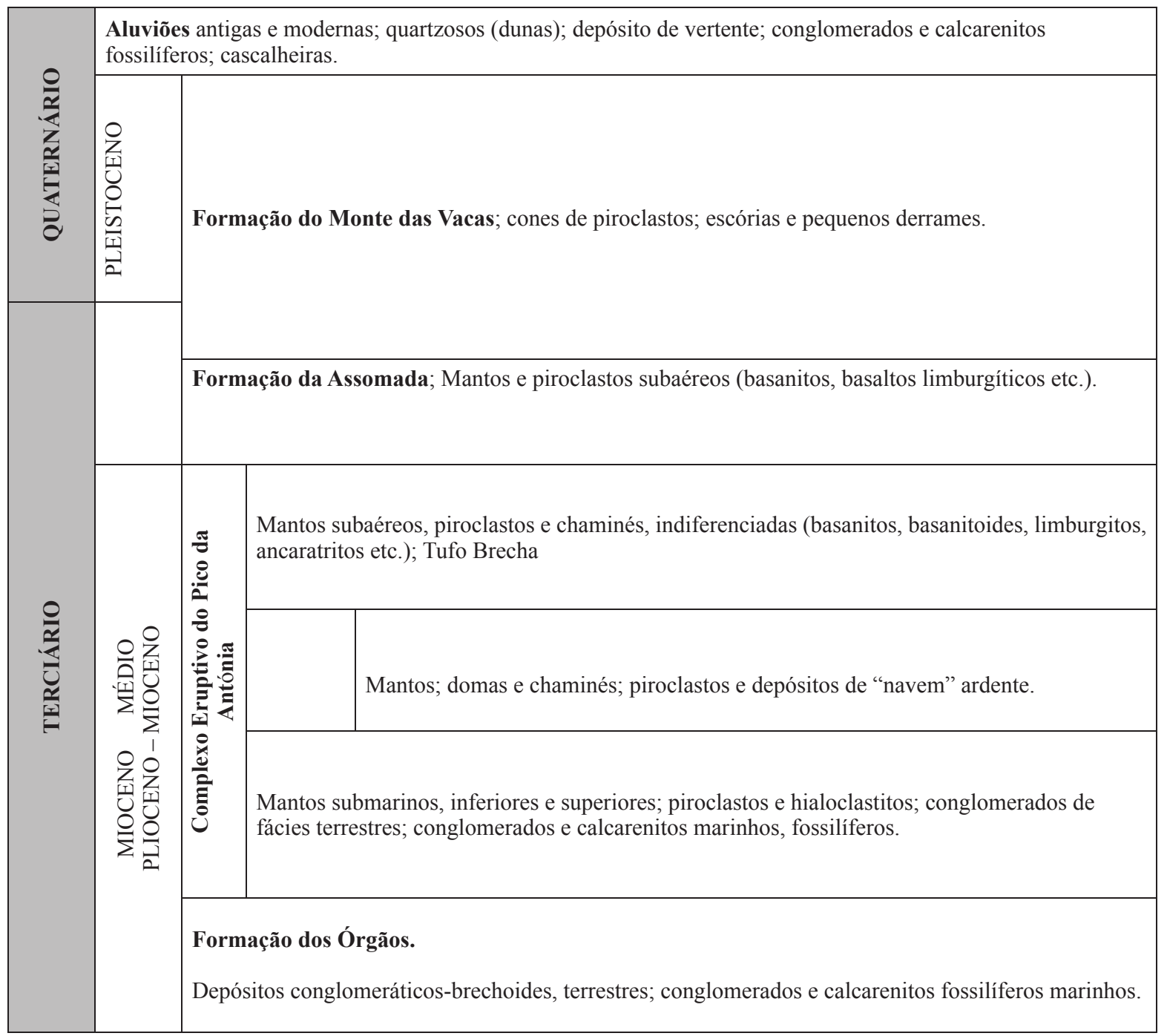

Figura 2 - Esboço lito-estratigráfico da Ilha de Santiago.

Fonte: SERRALHEIRO, 1973.

- Orla Costeira - apresenta uma linha de costa de $148 \mathrm{~km}$ bastante complexa, de recorte variado, com inúmeras reentrâncias e saliências, traduzindo a ação contínua e importante dos alísios sobre o movimento e intensidade da abrasão das ondas. Constituída, na sua maior extensão, por escarpas acantiladas e nas áreas baixas desenvolvem pequenas planícies. Na costa oriental, as escapas são mais baixas e interrompidas pelas porções terminais de vales amplos, dando origem às várzeas e algumas praias. Na parte sul da ilha, a escarpa entre os vales de São Tomé e a baía do Porto da Praia atinge alturas da ordem dos 30 metros e as praias limitam-se à foz das ribeiras;

- Planícies Litorâneas - correspondem à área de terras baixas nas zonas costeiras. São constituintes de depósitos sedimentares recentes com composição de sedimentos finos, que variam desde argilas avermelhadas e esbranquiçadas aos arenitos, calcários, geralmente detríticos, 
organogênicos, margas e conglomerados das Formações dos Órgãos e dos Flamengos que se assentam sobre a série de base. Entre a Vila do Tarrafal e Chão Bom, estende-se uma planície com cotas entre 6 e 10 m. Há ocorrências de dunas dispersas;

- Planícies e os Terraços Fluviais - caracterizam-se por possuir relevo plano, oriundo da acumulação de sedimentos inconsolidados quaternários. Estão diretamente subordinadas à ação dos processos de deposição fluvial constituídas por materiais finos, grosseiros e cascalhentos com inclusões de materiais piroclásticos e hialoclásistos. Normalmente estão encaixados em vertentes acantiladas em forma de canyons.

\section{Condições climáticas}

A Ilha de Santiago encontra-se situada numa vasta zona de clima árido e semiárido, que atravessa a África desde o Atlântico ao mar vermelho. Essa zona corresponde a uma faixa de altas pressões anticiclônicas, que se mantem estacionárias a maior parte do ano e desempenha papel importante na circulação atmosférica, separando a zona quente da zona temperada.

A ilha tem um ritmo habitual de tempo com característica tropical oceânica, baixa amplitude térmica e temperatura anual elevada. Possui como elemento essencial da dinâmica atmosférica a frequência dos ventos alísios, que sopram durante o ano inteiro, dando singularidade ao clima local. A umidade caracteriza-se, segundo Amaral (2007), por ser constantemente elevada e torna-se um fator que contribui para o adensamento de nuvens que diuturnamente adquirem estabilidade e condições de nebulosidade em função das condições de altas temperaturas. Outro aspecto a ser destacado é a forte influência da altitude, que representa obstáculo ao deslocamento das massas de ar, trazendo implicações locais significativas.

As diferenças climáticas locais e microclimáticas da ilha de Santiago decorrem do seu relevo fortemente dissecado e da posição da vertente oriental, que é favorecida pela exposição aos deslocamentos das massas de ar. Assinalam-se os aspectos relacionados à radiação solar e ao regime advectivo das chuvas, que beneficiam a vertente leste da ilha, ao contrário do que se constata na vertente oposta. Assim, os fatores geoambientais são condicionantes da ocupação humana e apresentam um contexto claramente diferenciado nas vertentes oriental e ocidental.

De acordo com Amaral (2007), distinguem-se duas estações principais que definem o clima da ilha: a estação mais seca ou período das brisas, entre os meses de dezembro a junho, quando a declinação solar e, com efeito, o recebimento de mais energia volta-se para o hemisfério sul; e a estação das chuvas, de agosto a outubro. Julho e novembro são meses de transição entre uma e outra estação. A estação chuvosa tem, por consequência, curta duração e o regime pluviométrico adquire forte irregularidade.

A análise temporal, entre os anos de 1996 a 2005, das médias mensais e anuais de temperatura e precipitação da Estação Meteorológica da Praia permite observar a variação dos parâmetros climatológicos e sua respectiva dinâmica de distribuição no decorrer do ano. Nota-se a regularidade das temperaturas anuais, sendo o mês de janeiro o mais frio, com média de $23,5^{\circ} \mathrm{C}$, sendo outubro o mês mais quente, com média de $27,5^{\circ} \mathrm{C}$. Tanto o mês mais frio como o mais quente colocam-se $2,0^{\circ} \mathrm{C}$ abaixo e acima da temperatura média anual de $25,5^{\circ} \mathrm{C}$, resultando numa amplitude térmica baixa, de $4,0^{\circ} \mathrm{C}$. O progressivo crescimento das curvas de temperatura durante os primeiros meses do ano e o consequente início das chuvas estão relacionados à alternância de aquecimento e à chegada do solstício de verão no hemisfério norte, fenômenos que justificam os elevados índices entre julho e outubro. O declínio das temperaturas, conjuntamente com a redução pluviométrica a partir do mês de outubro, associa-se com o afastamento da linha de radiação solar e o advento do solstício de verão no hemisfério sul, provocando parâmetros reduzidos no início do ano.

O panorama de diferenciações climáticas no conjunto da ilha é claramente percebido na leitura da tabela 1, onde são comparados dados referentes às três estações meteorológicas. Com as médias de temperatura e precipitação dos anos de 1996 a 2005, destacam-se, inicialmente, os dados da estação de São Jorge dos Órgãos, localizada no interior montanhoso, ainda na vertente a barlavento. Essa estação possui médias de precipitação superiores às outras duas, além de temperaturas relativamente menores. Já na estação da Praia, localizada na faixa litorânea, as médias de temperatura tomam a frente em comparação às demais. No entanto a precipitação aparece em menor número. Nota-se também que, em relação à estação de São Jorge dos Órgãos, a estação de Chão Bom, mais a oeste da ilha, apresenta menores índices de precipitação, conjuntamente a maiores índices de temperaturas médias anuais. 
A variação da precipitação tem forte influência na distribuição das formações vegetais e no calendário agrícola que orienta a organização dos cultivos. Com o volume pluviométrico concentrado entre julho e novembro, há escassez no restante do ano. A irregularidade temporal é nitidamente notada, pois os meses de agosto e setembro concentram em torno de $60 \%$ da precipitação total.

Tabela 1 - Dados termopluviométricos de três estações de Cabo Verde

\begin{tabular}{l|c|c|c|c|c|c}
\hline \multirow{2}{*}{ ANO } & \multicolumn{2}{|c|}{ EST. DA PRAIA } & \multicolumn{2}{c|}{ EST. S. JORGE DOS ORGÃOS } & \multicolumn{2}{c|}{ EST. CHÃO BOM } \\
\cline { 2 - 7 } & $\begin{array}{c}\text { Precipitação } \\
\text { Total }\end{array}$ & $\begin{array}{c}\text { Temperatura } \\
\text { Média }\left({ }^{\circ} \mathrm{C}\right)\end{array}$ & $\begin{array}{c}\text { Precipitação } \\
\text { Total }\end{array}$ & $\begin{array}{c}\text { Temperatura } \\
\text { Média }\left({ }^{\circ} \mathrm{C}\right)\end{array}$ & $\begin{array}{c}\text { Precipitação } \\
\text { Total }\end{array}$ & $\begin{array}{c}\text { Temperatura } \\
\text { Média }\left({ }^{\circ} \mathrm{C}\right)\end{array}$ \\
\hline 1996 & 17,8 & 25,2 & 282,2 & 22,7 & 51,3 & 25,8 \\
\hline 1997 & 154,5 & 27,9 & 341,2 & 22,9 & 83,9 & 26,5 \\
\hline 1998 & 45,8 & 25,2 & 297,5 & 23,0 & 69,7 & 26,4 \\
\hline 1999 & 216,5 & 25,2 & 663,0 & 23,3 & 664,3 & 26,3 \\
\hline 2000 & 267,4 & 25,2 & 454,0 & 22,1 & 172,1 & 24,4 \\
\hline 2001 & 87,6 & 25,2 & 434,1 & 22,1 & 367,7 & 25,7 \\
\hline 2002 & 41,2 & 25,2 & 258,6 & 22,6 & 185,7 & 25,8 \\
\hline 2003 & 186,2 & 26,1 & 713,2 & 22,7 & 526,3 & $*$ \\
\hline 2004 & 171,5 & 26,2 & 408,3 & 22,1 & 229,1 & $*$ \\
\hline Média & 179,7 & 26,3 & 405,4 & 22,5 & 69,6 & $*$ \\
\hline
\end{tabular}

As diferenças de parâmetros climáticos como a temperatura e a precipitação são reveladas, também, espacialmente dentro de Santiago. O cenário fisiográfico de características montanhosas da ilha provoca distinções. O gradiente altimétrico confere às áreas mais elevadas características paisagísticas relacionadas a condições de maior umidade, que atribuem às regiões litorâneas a que estão ligadas maior aridez.

O fato mais relevante do clima local é a frequência de secas recorrentes realizadas durante 265 anos (1718-1983), que mostraram 97 anos de secas mais ou menos severas (1 ano de seca em cada 3 anos). Durante o mesmo período, verificaram-se 14 secas com duração de mais de 3 anos consecutivos (AMARAL, 2007).

Em face da interação dos fatores geomorfológicos, hidroclimáticos e fitoecológicos, considerou-se à luz de estudos anteriores (DINIZ; MATOS, 1986) o seguinte zoneamento bioclimático para o Arquipélago de Cabo Verde:

- zona árida - faixa litorânea ocidental entre 0 e $200 \mathrm{~m}$ de altitude com pluviometria anual inferior a $300 \mathrm{~mm}$. A vegetação, geralmente, é do tipo estepe herbácea, sendo freqüente em exposições rochosas e solos desnudos.

. zona semiárida-subúmida - situa-se entre 200 e 400 m de altitude, com uma pluviometria interanual que oscila entre 300 e $600 \mathrm{~mm}$. Embora essa zona seja problemática para a agricultura, ela é praticada nos locais em que há maior regularidade pluviométrica. A vegetação tem espécies lenhosas;

. zona subúmida - está localizada entre 400 e 600 m de altitude, com uma pluviometria interanual que oscila entre 400 e $600 \mathrm{~mm}$. Essa zona é mais vocacionada para a agricultura, podendo-se encontrar aqui várias espécies lenhosas, arbustivas e arbóreas disseminadas pelos campos agrícolas, tais como acacia farmesiana (espinho preto), acacia nilotica (espinho preto), anacardium occidentale (cajueiro), dentre outros;

- zona úmida - está situada acima dos $700 \mathrm{~m}$ de altitude, com uma pluviometria média anual superior a $600 \mathrm{~mm}$. Em termos de produção agrícola e forrageira, é a mais produtiva.

\section{Recursos hídricos superficiais e subterrâneos}

Os recursos hídricos superficiais da Ilha de Santiago, segundo Ventura e Mascarenhas (2009), estão estimados em 56 milhões de m3/ano. Esses recursos praticamente não são explorados devido à inexistên- 
cia de dispositivos de captação e de armazenamento. Desse modo, é a água subterrânea o recurso hídrico mais utilizado nessa ilha, representando fonte de abastecimento para as zonas rurais, sendo explorada em nascentes e furos.

Com respeito aos recursos hídricos subterrâneos, estão estimados em 26 milhões de $\mathrm{m}^{3} /$ ano. A ilha recebe mais de 80 milhões de $\mathrm{m} 3$ /ano de água, concentrados no interior da ilha, na época chuvosa. As maiores disponibilidades correspondem às áreas circundantes dos maciços montanhosos e do planalto de Santa Catarina, setores considerados como os grandes aquíferos naturais.

A água do mar dessalinizada é utilizada apenas na cidade da Praia e pode ser utilizada para abastecimento das populações, apesar de os custos associados serem elevados. A tendência de evolução é no sentido crescente devido à situação de seca prolongada no país. Toda a água é fornecida após ter sido submetida à desinfecção com o hipoclorito de cálcio a $70 \%$ ou de sódio à $35 \%$ e controlado o nível de cloro residual livre.

Com respeito às condições geológicas de Santiago, pode-se dizer que depósitos aluvionares ou aluviões são os mais favoráveis e encontram-se à jusante da Ribeira Seca. São compostos por materiais grosseiros de elevada permeabilidade. Essas aluviões conseguem atingir uma profundidade de $30 \mathrm{~m}$ e constituem dreno natural das formações vulcânicas permeáveis, como os depósitos de pillow-lavas. Formam um importante aquífero, favorecendo a descarga para o mar e, por vezes, a intrusão salina quando o aquífero é sobre-explorado.

A Formação dos Órgãos é constituída de litologias que não permitem a formação de um aquífero favorável, pelo fato de que as rochas constituintes, quando molhadas, formarem camadas impermeáveis que impossibilitam recargas significativas. Aproximadamente $38 \%$ da bacia estão cobertas por esta formação (estende-se por toda a bacia à montante de São Cristóvão até a parte central da bacia de Ribeira Seca).

Quanto à Formação do Pico de Antónia, por ser constituída por depósitos de pillow-lavas e piroclastos de grande permeabilidade, favorece a recarga natural da bacia e está situada na parte média e jusante da bacia, contribuindo grandemente para a recarga do aquífero e os furos executados

\section{a) Caracterização das bacias hidrográficas}

$\mathrm{Na}$ ilha de Santiago, podem-se destacar algumas das principais bacias hidrográficas de acordo com Heitor e Pina (2003, p. 822):

- Bacia do Tarrafal - está situada na face setentrional da Serra da Malagueta, sendo dividida em duas sub-bacias A e B. Bacia de Tarrafal A: a quantidade total de água explorável é estimada em cerca de 2.166 milhões de $\mathrm{m}^{3} / \mathrm{ano}$, ou seja, $5.934 \mathrm{~m}^{3} / \mathrm{dia}$. O aquífero principal localiza-se na formação do Pico de Antónia, mas a maior parte da água subterrânea é armazenada no sopé setentrional da Serra da Malagueta. Bacia do Tarrafal B: sua área de captação é pequena com formação aquífera fina, dificultando o desenvolvimento da água subterrânea. Por isso, o caudal volumétrico deve ser limitado a 0,529 milhões de $\mathrm{m}^{3} / \mathrm{ano}$, ou $1.449 \mathrm{~m}^{3} /$ dia;

- Bacia de Santa Cruz - está localizada na face nordeste da Serra do Pico da Antónia, sendo dividida em três sub-bacias, incluindo também a área de captação da Ribeira Seca. Devido à estreita e fina distribuição da Formação do Pico de Antónia, o seu potencial de exploração é baixo, com a água a ser extraída da camada de depósitos aluviais;

- Bacia de Santa Catarina - corresponde ao setor meridional da Serra da Malagueta e a Oeste da Serra do Pico de Antónia, incluindo três principais áreas de captação: a Barca, do Charco e das águas que fluem em direção a Oeste;

- Bacia de São João Batista - está localizada no setor sudoeste da Serra do Pico de Antónia. As áreas ao longo dos alinhamentos apresentam algumas zonas ricas em fissuras favoráveis para a recarga da água subterrânea, uma vez que o nível de água na formação do Pico é geralmente baixo. Cuidados especiais devem ser tomados quando da definição dos pontos de perfuração;

- Bacia da Praia - está situada na bacia localizada na zona mais meridional da ilha. É coberta pelos aquíferos da formação do Pico de Antónia. A espessura dos aquíferos na área é favorável para a exploração, com forte potencial de recarga abundante da água subterrânea; 
- Bacia da Ribeira Seca - corresponde à maior bacia da Ilha de Santiago, com uma área aproximada de $70 \mathrm{~km}^{2}$. Desenvolve-se na fachada oriental com maior precipitação, entre o Maciço do Pico de Antónia (1.350 m) e a costa leste a sul de Pedra Badejo. As regiões mais suscetíveis continuam a ser as do setor sudeste da bacia, a que se associam as vertentes dos vales mais encaixados, em particular dos setores central e oriental, bem como as escarpas rochosas a oeste, na borda do Maciço do Pico da Antónia.

\section{Solos predominantes}

Os solos de Santiago são desenvolvidos a partir de rochas vulcânicas e caracterizados, de forma geral, pela predominância de solos rasos, acentuada pedregosidade, ausência de matéria orgânica e fraca capacidade de retenção de água. No entanto são ricos em elementos minerais.

O clima é o fator que interfere na velocidade e no modo de alteração das rochas, bem como na rapidez de decomposição da matéria orgânica na formação dos solos. Em Santiago, esse processo ocorre lentamente, ficando limitado a um período demasiadamente curto, período que vai de agosto a outubro. Pode-se afirmar, portanto, que a água é o principal fator limitante no desenvolvimento dos solos da ilha.

Além dos componentes ambientais (clima e relevo), a vegetação também facilita a exposição dos solos aos processos erosivos, pois o desmatamento e a distribuição muito irregular das espécies vegetais tornam os solos suscetíveis à erosão (AMARAL, 2007). A erosão acaba expondo os horizontes mais profundos dos solos e consequentemente os afloramentos das rochas, impedindo a evolução completa dos solos e comprometendo a sua capacidade produtiva.

As classes de solos predominantes na ilha de Santiago do Arquipélago de Cabo Verde foram classificadas em 10 (dez) grupos principais de solos, de acordo com a FAO/UNESCO (1968, 1989 apud DINIZ; MATOS, 1986, 46) e correlacionadas com a classificação Brasileira (EMPRESA BRASILEIRA DE PESQUISA PECUÁRIA, 2006) em: Fluvisols (Neossolos flúvicos), Leptsols (Neossolos litólicos), Arenosols (Neossolos quartzarênicos), Andosols (sem correlação brasileira), Vertisols (Vertissolos), Cambisols (Cambissolos), Phaeozems (Chernossolos), Luvisols (Luvissolos), Lixisols (Argissolos) e Regosols (Neossolos regolíticos):

. Fluvisols - são oriundos de depósitos não consolidados bastante heterogêneos do ponto de vista granulométrico, por meio dos processos alúvio-coluviais, localizados nas estreitas margens das linhas de água cujos cursos se encontram encaixados na sua maior extensão. São solos considerados mais produtivos, tendo sua expressão maior na Ribeira Seca;

. Leptsols - ocorrem distribuídos em toda a ilha, ocorrendo mais especificamente nos setores de maior declive em diferentes condições climáticas. São solos rasos e muito delgados ( 10 a 20 cm de espessura ou menos) com abundância de pedregosidade e rochosidade. Desenvolvem-se sobre substrato consolidado de basalto, textura arenosa ou média, normalmente cascalhenta, distribuídos nas diferentes zonas climáticas;

Arenosols - estão distribuídos nos setores rebaixados dos relevos. São geralmente oriundos dos sedimentos arenosos das dunas. Possuem alta permeabilidade e baixo conteúdo de matéria orgânica. Desse modo, são solos sem grande interesse agrícola;

Andosols - são solos que possuem propriedades ândicas e textura fina. Trata-se, por conseguinte, de solos com fertilidade química natural relativamente baixa, no entanto possuem características físicas excepcionalmente favoráveis;

- Vertisols - são solos argilosos relacionados com superfícies aplainadas, mais especificamente em áreas ligeiramente deprimidas, em geral de coloração acastanhada, com estrutura prismática grosseira, superfícies lisas e brilhantes entre os agregados e fendilhamento característico. Estão normalmente associados às planícies;

- Cambisols - em geral, ocorrem sob clima que varia de semiárido a subúmido, originado, sobretudo, de rochas basálticas. Menos frequentemente se formam a partir de tufos e só muito 
raramente são originários de piroclastos grosseiros. Predominam solos com espessura superior a $50 \mathrm{~cm}$. De modo geral, apresentam razoável potencialidade agrícola;

- Phaeozems - encontram-se nas superfícies das achadas das zonas subúmidas e úmidas, com áreas mais aplainadas, favoráveis à argiluviação e a um aumento do teor em matéria orgânica. São solos de textura fina (franco-argiloso-limosos ou argilosos) relativamente espessos, de coloração pardo-escura ou pardo-vermelho-escura no horizonte superficial, caracterizando-se por uma boa estrutura ao longo do perfil;

. Luvisols - são solos moderadamente intemperizados, pois contêm menos Al-Fe-Ti e óxidos do que os Lixisols. Ocorrem em relevos moderamente dissecados. Possuem boa drenagem interna, sendo potencialmente adequados para uma ampla variedade de usos agrícolas;

Lixisols - são encontrados, predominantemente, nos setores mais úmidos e em relevos fortemente dissecados. São solos fortemente intemperizados com argila de atividade baixa e moderada a elevada saturação por bases. São, de modo geral, solos com elevado potencial agrícola, apresentando, entretanto, em determinadas áreas, problemas de relevo, principalmente onde as precipitações pluviométricas são mais elevadas;

- Regosols - ocorrem em áreas montanhosas sob floresta. São solos profundos, bem drenados e de textura média. Apresentam baixa capacidade de retenção de água e alta permeabilidade à água, tornando-os sensíveis à seca.

\section{Cobertura vegetal}

As características das formações vegetais predominantes são estépicas, com presença de arbustos ou pequenas árvores dispersas. Representam relíquias de formações mais densas, gradualmente condicionadas por fatores ecológicos, de natureza climática e antrópica. Sua evolução resulta das sucessivas estiagens e a crescente degradação causada pelo homem mediante uso inadequado.

Com respeito ao estudo da cobertura vegetal e das comunidades da Ilha de Santiago, de acordo com Diniz e Matos (1986), estão agrupadas em unidades agroecológicas com base nas características fisionômica, florísticas e ecológicas, resultando no total de 100 (cem) inventários que permitiram os estudos taxonômicos da flora de Cabo Verde.

Segundo os autores supracitados, a composição florística, a fisionomia e as condições fisiográficas serviram para classificar as comunidades em:

I . Comunidades das Praias;

II. Comunidades das Arribas Costeiras;

III. Comunidades das Ribeiras e dos Vales Abertos;

IV. Comunidades das Zonas Áridas dos Vales Abruptos, dos Coroamentos Rochosos e dos Cones Vulcânicos;

V. Comunidades das Zonas Semiáridas, dos Coroamentos Rochosos e dos Cones Vulcânicos;

VI. Comunidades das Zonas Subúmidas, dos Coroamentos Rochosos e dos Cones Vulcânicos;

VII. Comunidades das Zonas Úmidas Montanhosas e dos Coroamentos Rochosos e dos Cones Vulcânicos (quadro 2). 
Quadro 2 - Comunidades e suas respectivas espécies

\begin{tabular}{|c|c|}
\hline & Espécies \\
\hline I. $\mathrm{C}$ & unidades das Praias \\
\hline 1 & Ipomoea brasiliensis, Patellifolia procubens, Sporobulus spicatus \\
\hline 2 & Zygophyllum simplex, Philoxerus vermicularis, Tribulus cistoides \\
\hline II.C & lunidades das arribas costeiras \\
\hline 3 & Sarcostema daltonii, Asteriscus vogelli, Roccella spp. \\
\hline 4 & Sarcostema daltonii, Aloe barbadensis, Campylanthus glaber \\
\hline III. & MUNidAdes das Ribeiras E dos Vales Abertos \\
\hline 5 & Clitoria ternata, Boerhavia repens, Corchorus olitorius \\
\hline 6 & Amaranthus spinosus, Chenopodium murale, Cynodon dactylon \\
\hline 7 & Amaranthus spinosus, Argemone mexicana, Centaurea melitensis \\
\hline 8 & Amaranthus spinosus, Plantago major, Sanchus oleraceus \\
\hline $\begin{array}{l}\text { IV.C } \\
\text { Cor }\end{array}$ & $\begin{array}{l}\text { iUnidades das Zonas Áridas (Litorâneas e SubLitorâneas) dos Vales Abruptos, dos } \\
\text { MENTos Rochosos, e dos Cones vulcânicos }\end{array}$ \\
\hline 9 & Acacia albida, Ziziphus mauritanius, Jatripha curcas \\
\hline 10 & Cleome brachycarpa, Cleome viscosa, Indigofera cordifolia \\
\hline 11 & Cleome viscosa, Indigofera cordifolia, Aristida cardosoi \\
\hline 12 & Ipomoea assarifolia, Sida coutinhoi \\
\hline 13 & Cleome viscosa, Bidens bipinarte, Sida coutinhoi \\
\hline 14 & Ipomoea assarifolia, Sida coutinhoi \\
\hline 15 & Heliotropium pterocarpum, Leucas mertinicensis, Cleome viscosa \\
\hline 16 & Heliotropium pterocarpum, Peristhrophe bicalyculata, Bidens bipinarte \\
\hline 17 & Foraskaolea procridifolia, Trichodesma africanum, Nicromeria forbesii \\
\hline $\begin{array}{ll}\text { V.C } \\
\text { Cos }\end{array}$ & 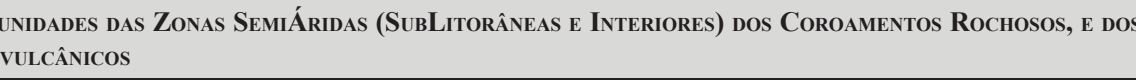 \\
\hline 18 & Caylusea canescens, Leucas martinicensis, Borreria verticillata \\
\hline 19 & Blainvillea gayana, Caylusea canescensis, Bidens bipinata \\
\hline $\begin{array}{l}\text { VI. } \\
\text { Cor }\end{array}$ & 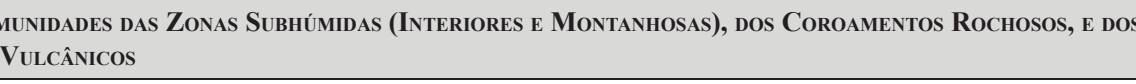 \\
\hline 20 & Blainvilea gayana, Desmanthus virgathus, Pennisetum polysthachyon \\
\hline 21 & Verbascum capitis-viridis, Diplotaxis gracilis, Furcraea gigantea \\
\hline 22 & Euphorbia tuckeyana, Echium hypertropicum, Lantana camara \\
\hline 23 & Lotus melilotoides, Micromeria forbesii, Forskaolea procridifolia \\
\hline VII & munidades das Zonas Úmidas Montanhosas e dos Coroamentos Rochosos \\
\hline 24 & Andropogon goyanensis, Panicum maximum, Campanula jacoboea \\
\hline 25 & Sideroxylon marmulano, Verbascum capitis-viridis, Fucraea gigantea \\
\hline
\end{tabular}

Fonte: DINIZ \& MATOS (1986)

No que diz respeito às 7 (sete) comunidades do zoneamento agroecológico, estas apresentaram um total de 25 associações, sendo a maioria representada por 3 (três) espécies, num total de 23, e as demais com 2 (duas) espécies com 2 (duas) associações.

\section{RESULTADOS E DISCUSSÕES}

A caracterização e a delimitação das unidades geoambientais foram precedidas de uma análise sobre cada componente, dando ênfase na geomorfologia, por ser mais facilmente identificada e passível de uma delimitação rigorosa e precisa. Levando em conta também que cada compartimento tende a ter padrões próprios de arranjamento de solos e características singulares quanto aos aspectos fitofisionômicos. Por 
OLIVEIRA, V. P. V.
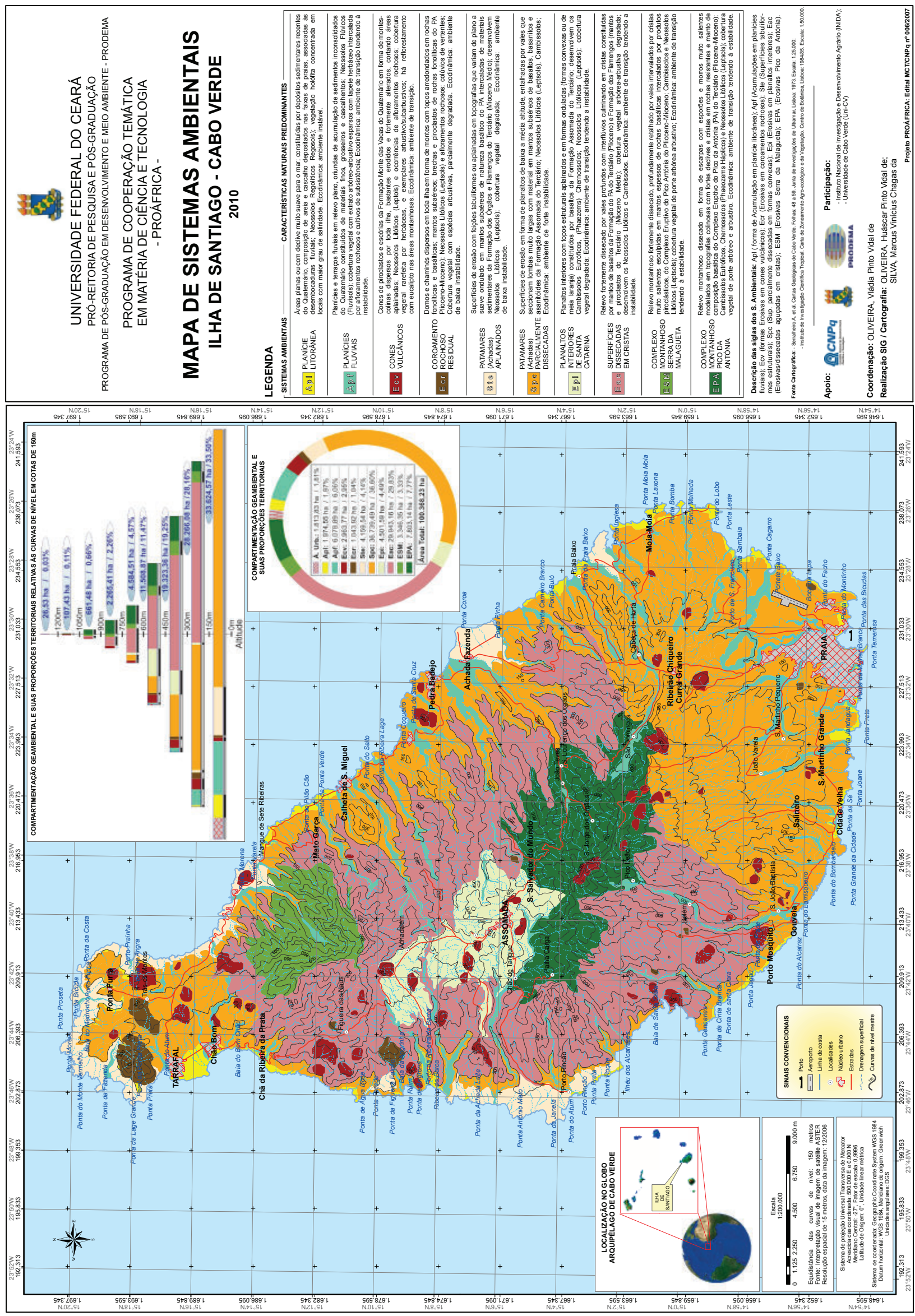

Figura 3 - Mapa de Sistemas Ambientais 
consequência, os padrões de ocupação foram também influenciados. Desse modo, identificaram-se 10 (dez) sistemas ambientais que estão representados no Mapa de Sistemas Ambientais (Figura 3) definidos em: 1. Planície Litorânea; 2. Planícies Fluviais; 3. Cones Vulcânicos; 4. Coroamentos Rochosos; 5. Complexo Montanhoso Pico de Antónia; 6. Complexo Montanhoso Serra da Malagueta; 7. Planaltos Interiores Santa Catarina; 8. Superfícies Dissecadas em Cristas; 9. Patamares Parcialmente Dissecados; 10. Patamares Aplainados (quadro 3, 4, 5, 6 e 7).

Com referência aos indicadores biofísicos de desertificação (IBFD) aplicados a cada sistema ambiental obtiveram-se os resultados mostrados nas figuras (quadro 8 e 9):

$\mathrm{Na}$ análise da desertificação, com relação aos indicadores biofísicos IBFD (quadro 8) dos sistemas ambientais e aos índices (quadro 9), obtiveram-se os seguintes resultados:

- os Cones Vulcânicos e os Patamares Parcialmente Dissecados obtiveram os mais baixos valores de índice, 2,14 e 2,57, respectivamente, correspondendo ao índice biofísico de desertificação muito alto;

- a Planície Litorânea, os Cones Vulcânicos e os Patamares Parcialmente Dissecados obtiveram resultados iguais valores de índice biofísico de desertificação, correspondendo a 2,7, enquadrando-os na categoria de alto índice de desertificação;

- os sistemas ambientais como o Complexo Montanhoso Pico de Antónia e Complexo Serra Malagueta obtiveram os maiores valores de 3,29 em ambos, correspondendo ao índice baixo de desertificação;

. da análise dos indicadores biofísicos de desertificação dos sistemas ambientais, verificou-se a ocorrência de dois grupos distintos com relação à variação do IBFD: os que variaram de valores de 2,14 a 2,71 (Cones Vulcânicos, Patamares Parcialmente Dissecados, Patamares Aplainados, Planícies Litorâneas e Coroamento rochosos), resultando índice muito alto de desertificação; e os que apresentaram variações de IBDF de 3,0 a 3,43, englobando os seguintes sistemas ambientais (Superfícies dissecadas em Cristas, Complexo Montanhoso Pico de Antónia, Complexo Serra de Malagueta e Planície Fluvial), enquadrando-se nos intervalos de muito baixo a baixo índice biofísico de desertificação.

\section{CONSIDERAÇÕES FINAIS}

A qualidade ambiental expressa o estado de conservação dos sistemas ambientais gerais e da biodiversidade, além das tendências da sucessão ecológica. Algumas recomendações assumem maior importância no sentido de controlar a expansão dos processos de desertificação:

. não ultrapassar a capacidade de suporte dos sistemas ambientais;

- adotar medidas conservacionistas no uso e ocupação da terra;

- evitar o uso em sistemas ambientais dotados de alta fragilidade ou instabilidade em face da erosão;

- nas áreas com vertentes acentuadas deve-se proceder a contenção de encostas através de geotecnologias (engenharia da restauração);

- para as áreas protegidas deve-se seguir preceitos da legislação ambiental decreto - Lei $n^{0}$ 3/2003 de Cabo Verde. Essas áreas se inserem no Parque Natural da Serra Malagueta e no da Serra de Pico de Antonia, ambas aprovadas pela Lei n ${ }^{\circ}$ 86/IV/1993 de 26 de junho do Decreto-Legislativo $n^{\circ} 14 / 1997$ de $1^{\circ}$ de julho, no artigo 6.2 - sugere-se a aplicação de um plano de manejo.

Assim, conforme os dados fornecidos por meio do diagnóstico e dos indicadores de desertificação, estes 


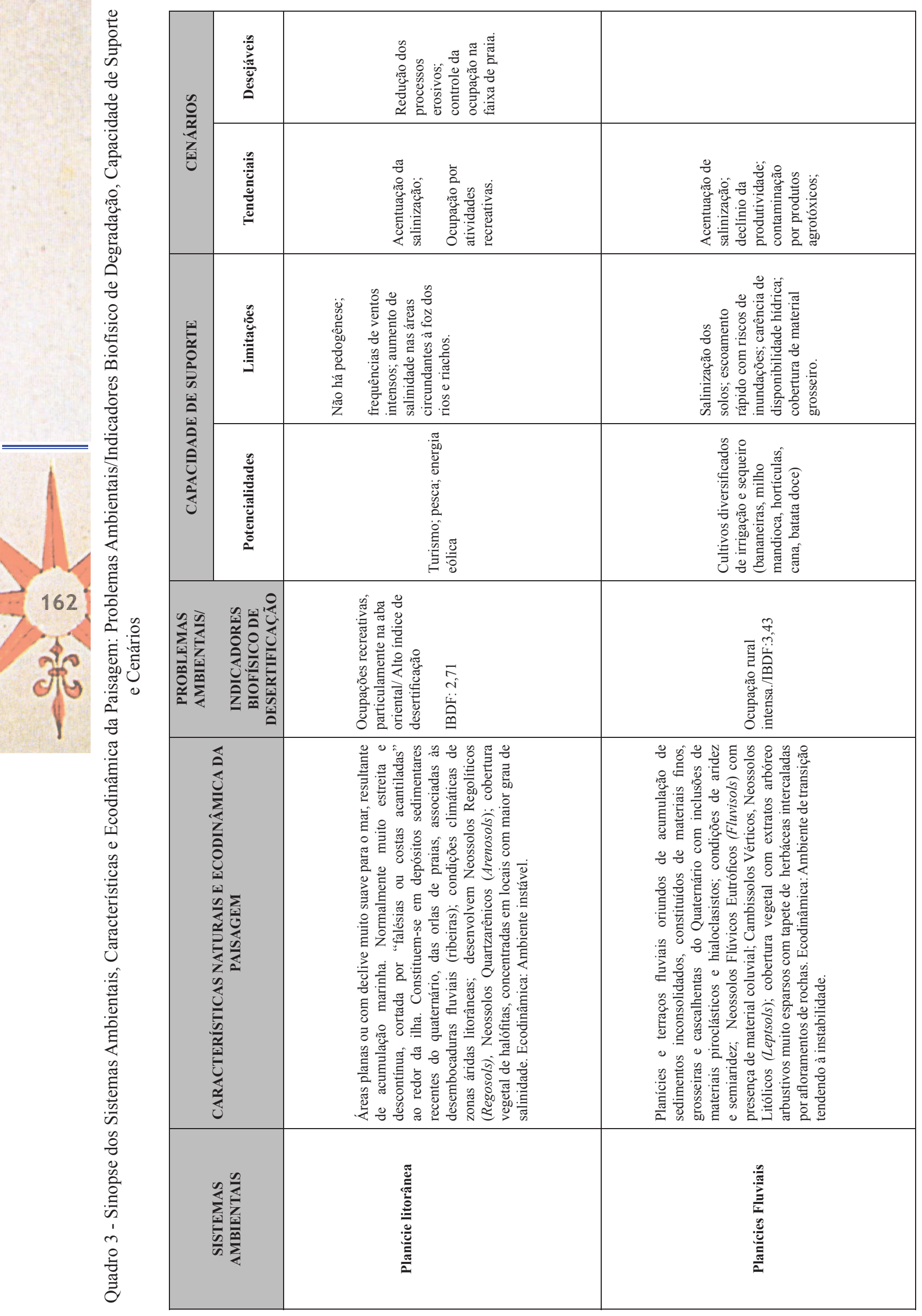




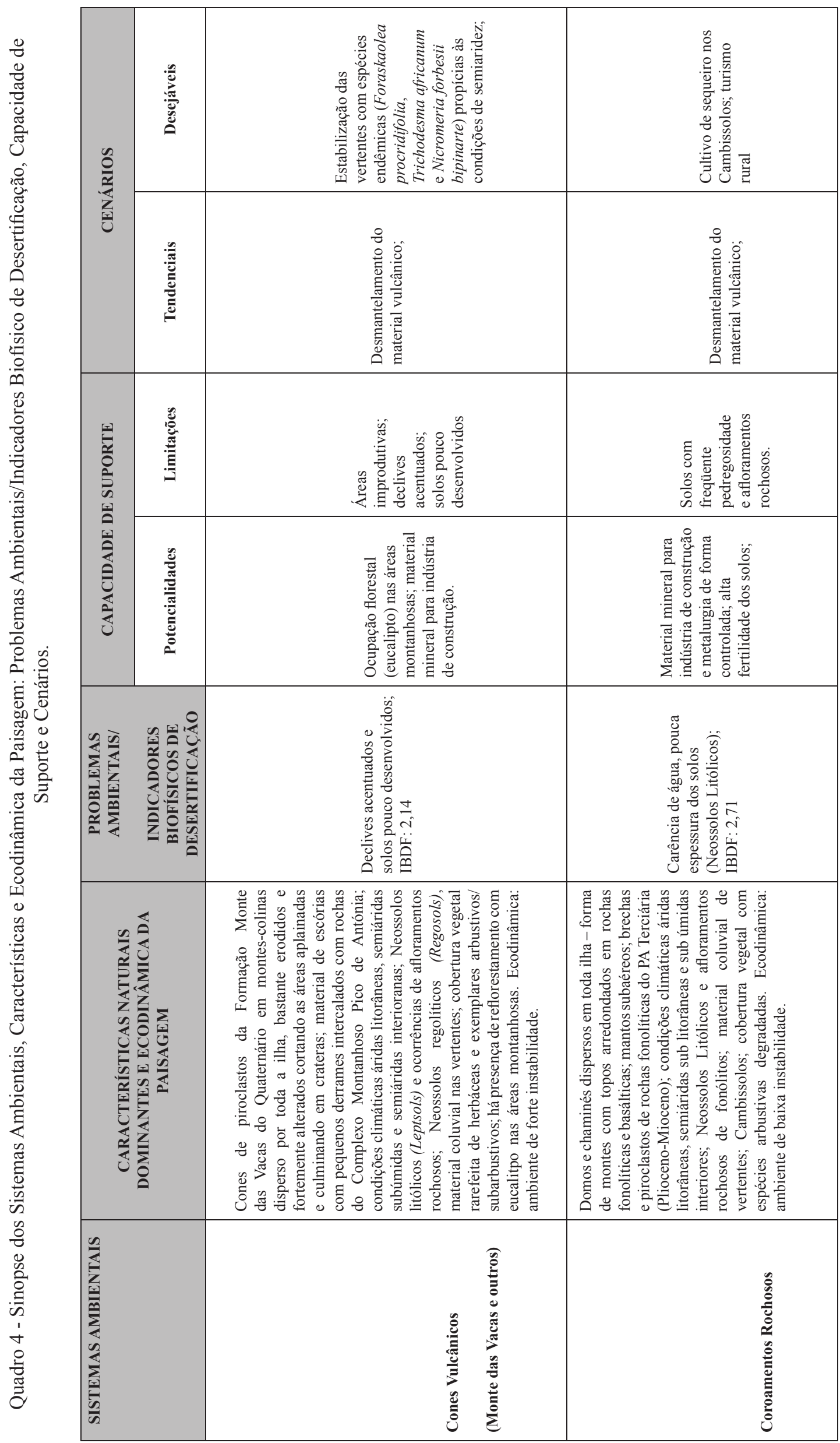


OLIVEIRA, V. P. V.

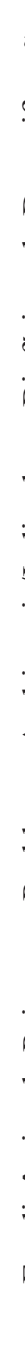

बैज

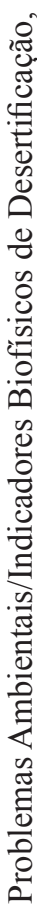

$\ddot{\Xi}$

总

可

तु 0

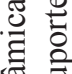

愹

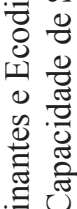

흥

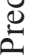

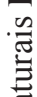

.్ֶ

营

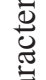

चี

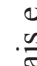

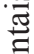

뮴

\&

:

is

in

윰

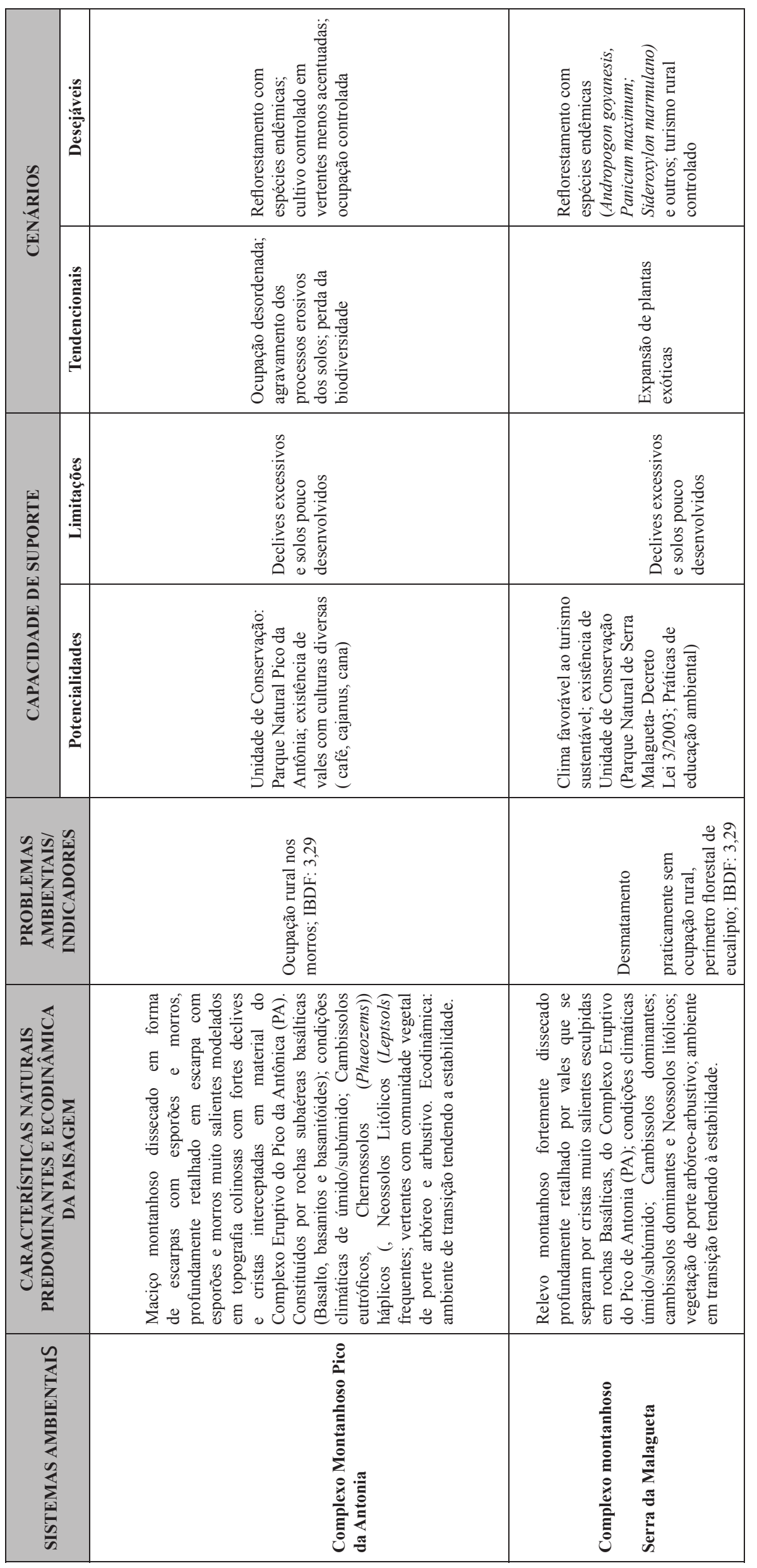

Mercator, Fortaleza, v. 10, n. 22, p. 147-168, mai./ago. 2011. 


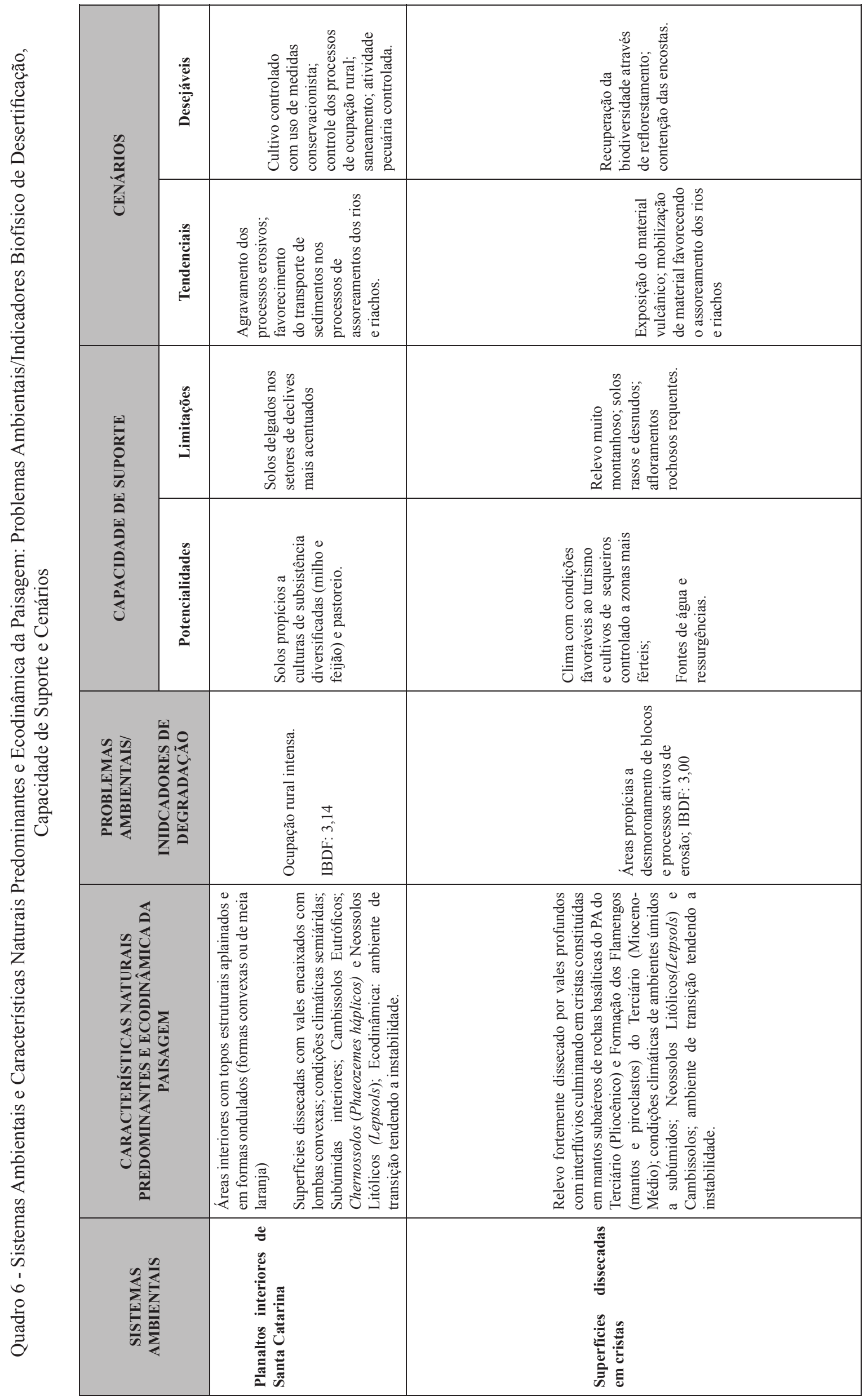


Quadro 8 - Indicadores biofísicos de desertificação dos Sistemas Ambientais e Medidas de Dispersão (variância, média, desvio padrão, coeficiente de variação e contribuição de cada indicador biofísico para o índice)

\begin{tabular}{|c|c|c|c|c|c|c|c|c|}
\hline \multirow{2}{*}{ SISTEMAS AMBIENTAIS } & \multicolumn{8}{|c|}{$\begin{array}{l}\text { INDICADORES BIOFÍSICOS DE DESERTIFICAÇÃO } \\
\text { IBFD }\end{array}$} \\
\hline & IBF1 & IBF2 & IBF3 & IBF4 & IBF5 & IBF6 & IBF7 & IBFD \\
\hline Planície Litorânea & 5 & 5 & 1 & 1 & 1 & 5 & 1 & 2,71 \\
\hline Planície Fluvial & 5 & 5 & 2 & 2 & 2 & 5 & 3 & 3,43 \\
\hline Cones Vulcânicos & 2 & 2 & 1 & 2 & 2 & 4 & 2 & 2,14 \\
\hline Coroamento Rochoso & 2 & 2 & 2 & 3 & 3 & 4 & 3 & 2,71 \\
\hline Complexo Montanhoso Pico Antônia & 2 & 1 & 4 & 3 & 4 & 4 & 5 & 3,29 \\
\hline Complexo Serra Malagueta & 2 & 3 & 3 & 3 & 3 & 4 & 5 & 3,29 \\
\hline Planaltos Interiores de Santa Catarina & 3 & 3 & 3 & 3 & 3 & 4 & 3 & 3,14 \\
\hline Superfícies Dissecadas em Cristas & 2 & 2 & 3 & 3 & 3 & 3 & 5 & 3,00 \\
\hline Patamares Parcialmente Dissecados & 2 & 4 & 4 & 2 & 2 & 2 & 2 & 2,57 \\
\hline Patamares Aplainados & 1 & 5 & 3 & 2 & 2 & 5 & 1 & 2,71 \\
\hline Média & 2,60 & 3,20 & 2,60 & 2,40 & 2,50 & 4,00 & 3,00 & 2,90 \\
\hline Desvio Padrão & 1,35 & 1,48 & 1,07 & 0,70 & 0,85 & 0,94 & 1,56 & 0,40 \\
\hline Coeficiente de Variação (\%) & 51,92 & 46,25 & 41,34 & 29,13 & 33,99 & 23,57 & 52,12 & 13,79 \\
\hline $\begin{array}{l}\text { Contribuição de cada indicador biofísico para o } \\
\text { Índice }\end{array}$ & 12,81 & 15,77 & 12,81 & 11,83 & 12,32 & 19,71 & 14,78 & \\
\hline
\end{tabular}

Fonte: OLIVEIRA, 2003.

propiciarão ferramentas para auxiliar no gerenciamento e gestão do uso e ocupação dos sistemas ambientais e de seus recursos naturais.

Em virtude de se constatar a ocorrência de extensas áreas em estado de desertificação, sugere-se a recuperação da biodiversidade com base no enriquecimento de espécies endêmicas ou adaptadas às condições ecológicas locais, principalmente nas encostas e margens ribeirinhas, e a implementação de programas e práticas de educação ambiental.

Quadro 9 - Índices Biofísicos de Desertificação

\begin{tabular}{|l|l|}
\hline \multicolumn{1}{|c|}{$\begin{array}{c}\text { ÍNDICE BIOFÍSICO DE } \\
\text { DESERTIFICAÇÃO }\end{array}$} & INTERVALOS \\
\hline Muito Baixo & $>3,36$ \\
\hline Baixo & $3,20-3,36$ \\
\hline Moderado & $2,80-3,19$ \\
\hline Alto & $2,64-2,79$ \\
\hline
\end{tabular}

Vale salientar, a necessidade de se propor a implementação de tecnologias simples, como a construção de cisternas ou similares para a capacitação e armazenamento de água da chuva, gerando bons resultados, a exemplo de políticas públicas aplicadas no estado do Ceará (Brasil).

Por fim, deve-se estimular o desenvolvimento de pesquisas voltadas para o melhoramento genético de espécies, permitindo a condição de tolerância com fenótipo adaptativo ao stress salino. 


\section{REFERÊNCIA BIBLIOGRÁFICA}

ABRAHAM, E.M.; BEEKMAN, G. B. Indicadores de la desertificación para América del Sul. IICA-BID ATN JF. Mendoza, Argentina: LaDyOT/IADIZA/CONICEF/IICA, 2006.

AMARAL, I. do. Santiago de Cabo Verde: a terra e os homens. 2. ed. Lisboa: Associação das Universidade de Língua Portuguesa; Centro de Estudos Geográficos da Universidade de Lisboa; Instituto de Investigação Científica Tropical; Universidade do Algarve; Universidade de Cabo Verde, 2007.

BRASIL,MMA. Programa de Ação Nacional de Combate à Desertificação. Brasília:Ed. MMA, 2004.

BRASIL. Ministério do Meio Ambiente (MMA). Programa de zoneamento ecológico-econômico: diretrizes metodológicas para o zoneamento ecológico-econômico do Brasil. Brasília, DF: Secretaria de Política para o Desenvolvimento Sustentável (MMA), 2001.

DINIZ, A.C; MATOS, G. C. de. Carta de zoneamento agro-ecológico e da vegetação de Cabo Verde. I - Ilha de Santiago. Lisboa: CEPdo IICT. 1986.

EMPRESA BRASILEIRA DE PESQUISA AGROPECUÁRIA (EMBRAPA). Sistema brasileiro de classificação de solos. 2. ed. Rio de Janeiro: EMBRAPA, 2006.

HEITOR, A. M; PINA, A. Águas subterrâneas em Cabo Verde: quantidade da água na Ilha de Santiago. In: SIMPÓSIO DE HIDRÁULICA E RECURSOS HIIDRICOS DOS PAÍSES DE LÍNGUA OFICIAL PORTUGUESA, 6., 2003, Lisboa Anais. Disponível em: <http://www.aprh.pt/6_sisluba/vol3_APRH_ LF_819_888.pdf. 10/10/2010>. Acesso em: 10 out. 2010.

MARQUES, M. M. Caracterização das grandes unidades geomorfológicas da Ilha Santiago (República Verde) Garcoa de Prt; Ser; Est; Agrn. Lisboa: IICT/ICE, 1990.

NAVONE, S. M. et al. Indicadores biofísicos de y desertificación em el noreste argentino: desarrolo metodológico. In: ABRAHAM, E.M.; BEEKMAN G.B. Indicadores de la desertificación para América del Sur. Mendoza, Argentina: Martín Fierro, 2006. p. 103-112.

OLIVEIRA, V.P.V. de. Sustainable use of natural resources in the municipality of Tauá-Ceará. In: GAISER, T. et al. Global change and regional impacts. Nova Iorque: Springer, 2003. p. 305-322.

OLIVEIRA, V.P. V. de et al. Análise integrada do Setor Oriental da Ilha de Santiago, em Cabo Verde - África. In: XIII SIMPÓSIO BRASILEIRO DE GEOGRAFIA FÍSICA APLICADA, 13., Viçosa, MG. Anais. Viçosa, MG: UFV, 2009.

SERRALHEIRO A. A Geologia da ilha de Santiago (Cabo Verde). Bol. Mus.Lab.Min.Geol. Fac.Ciências, Lisboa 14 (2), 1-218. 1976.

SERRALHEIRO, A .et al. - Carta Geológica da Ilha de Santiago (Escala 1:25.000). Junta de Investigação Científicas Ultramar. Lisboa, 11mapas. 1973.

SOUZA, M.J.N. Bases naturais e esboço do zonemaento geoambiental do estado do Ceará. In: LIMA, L. C.; ORAIS, J. O. de; SOUZA, M. J. N de. Compartimentação territorial e gestão regional do Ceará. Parte I. Fortaleza: FUNECE, 2000. p. 106-104.

TRICART, J. Ecodinâmica. Rio de Janeiro: FIBGE; SUPREN, 1977.

VENTURA, J. E.; MASCARENHAS, J. A problemática dos recursos hídricos em Santiago. In: CONGRESSO DE DESENVOLVIMENTO REGIONAL DE CABO VERDE, 1.; CONGRESSO LUSÓFONO DE CIÊNCIA REGIONAL, 2., 2009, Praia. Anais... Disponível em: <http://www.apdr.pt/ congresso/2009pdefrsess\%c3\%A30\%205/200A.pdf>. Acesso em: 9 nov. 2010.

Trabalho enviado em junho de 2011

Trabalho aceito em agosto de 2011 